\title{
Photodynamic Therapyの効果と問題点
}

\author{
Effects of Photodynamic Therapy \\ in Inoperable Early Stage Lung Cancer Patients
}

竹原有史 $\cdot$ 大崎能伸 $\cdot$ 藤内 智 $\cdot$ 山口修二・秋葉裕二

中野 均 $\cdot$ 藤兼俊明 $*$. 清水哲雄 $*$ ・坂井英一 $*$. 菊池健次郎

要旨：中枢型早期肺癌 8 例に対し photodynamic therapy(PDT)を施行した. 全例が Roentogenographically occult lung cancer (ROLC) で, 組織型は扁平上皮癌であった. TNM分類では, TisN0M0が 6 例 8 病巣 (多発癌 2 例), T 1 N0M0が 2 例 2 病巣であっ た. 腫瘍径は $10 \mathrm{~mm}$ 未満が 6 例 7 病巣, $10 \mathrm{~mm}$ 以上が 2 例 3 病巣であった. 治療効果の判 定は, PDTを施行した 2 週後の気管支鏡検査所見と, 2 週後及び 4 週後の喀痰細胞診に て総合的に判定した. PDTの結果, 1.8 症例中complete response (CR) を 5 例, Partial response $(\mathrm{PR})$ を 3 例得た。 2 . 深達度ではC $\mathrm{Cis} の 6$ 例中 5 例， 8 病巣中 6 病巣にCRを得 た. 3 .腫瘍径では $10 \mathrm{~mm}$ 未満の 6 例中 5 例, 7 病巣中 5 病巣にCRを得た. $4 . \mathrm{CR}$ の 1 例 2 病巣 (多発例), PRの 2 例 2 病巣に放射線治療を追加しCRを得た。 5 . 死因は, 5 例中 3 例が重複癌死, 2 例が他病死, 原発癌死はなかった. 生存期間は, 重複癌の進行で 8 力月後に死亡した 1 例を除いては39 120力月 (中間值50力月) で, 5 年以上の生存は 3 例 であった。

〔肺癌 $35(2): 127 \sim 132,1995$ 〕

Key words : Photodynamic therapy, Early stage lung cancer, Bronchofiberscope

\section{はじめに}

近年, 肺癌による死亡率の増加とともに肺癌 検診の普及, 特に喀痰細胞診の重要性が認識さ れるようになってきた。 その結果, 胸部X線写 真上無所見で喀痰細胞診陽性のRoentgenographically occult lung cancer (ROLC)の症例が 多く発見され，その診断と治療についての関心 が高まってきた. ROLC症例の多くは, 気管支鏡 検査によって診断される気管支原発の中枢型肺 癌である。組織型は扁平上皮癌が多く，リンパ 節転移，遠隔転移を伴わない早期肺癌であるこ とが多い.このような症例に対する第一選択の

旭川医科大学第 1 内科

* 国立療養所道北病院内科
治療は外科的療法で，その 5 年生存率は $90 \%$ を 越之 ${ }^{1)}$ 根治の可能性が高い.しかし，ROLCでは 高齢者が多く，肺気腫や塵肺などの基礎疾患に よる低肺機能症例が多いこと，さらには多発癌 や重複癌を合併することが少なくない2),3)など, 手術適応から外れる症例がしばしば経験される。 このような症例に対して1980年代前半から局所 的根治的治療法としてphotodynamic therapy (PDT)が行われるようになってきた.PDTの適 応については一応の基準が提案されているが, それによる照射範囲，治療効果判定時期と方法， 他の治療法との併用などと予後との関係を踏ま えた明確な指針はなお示されていないように思 われる。そこで今回我々は1982年から1993年に 
Table 1. Clinical characteristics and prognosis of patients.

\begin{tabular}{|c|c|c|c|c|c|c|c|c|c|c|}
\hline case & sex & age & type & location & TNM & form & size $(\mathrm{mm})$ & complication & prognosis & outcome \\
\hline \multirow[t]{2}{*}{1} & \multirow[t]{2}{*}{ M } & \multirow[t]{2}{*}{75} & \multirow[t]{2}{*}{ SCC } & 1)R. $\mathrm{B}^{1} \mathrm{~B}^{2} \mathrm{~B}^{3}$ & $\mathrm{Cis}$ & nodular & $15 \times 15$ & \multirow[t]{2}{*}{ COPD } & \multirow[t]{2}{*}{$48 \mathrm{M}$} & \multirow{2}{*}{$\begin{array}{l}\text { dead by } \\
\text { another carcinoma }\end{array}$} \\
\hline & & & & 2)R. $\mathrm{B}^{8} \mathrm{~B}^{9} \mathrm{~B}^{10}$ & Cis & nodular & $11 \times 12$ & & & \\
\hline 2 & M & 69 & $\mathrm{SCC}$ & R. $B^{1} B^{2}$ & Cis & $\begin{array}{l}\text { surface- } \\
\text { invasion }\end{array}$ & $6 \times 7$ & COPD & $62 \mathrm{M}$ & $\begin{array}{l}\text { dead by } \\
\text { another carcinoma }\end{array}$ \\
\hline 3 & M & 68 & $\mathrm{SCC}$ & L. $B^{3 a+b}$ & T1N0M0 & polyp & $5 \times 5$ & $\begin{array}{l}\text { pneumo- } \\
\text { coniosis }\end{array}$ & $39 \mathrm{M}$ & $\begin{array}{l}\text { dead by } \\
\text { brain bleeding }\end{array}$ \\
\hline 4 & M & 73 & $\mathrm{SCC}$ & L. $\mathrm{B}^{1+2} \mathrm{~B}^{3}$ & T1N0M0 & $\begin{array}{l}\text { surface- } \\
\text { invasion }\end{array}$ & $4 \times 11$ & $\begin{array}{l}\text { pneumo- } \\
\text { coniosis }\end{array}$ & $42 \mathrm{M}$ & $\begin{array}{l}\text { dead by } \\
\text { pneumonia }\end{array}$ \\
\hline 5 & $\mathrm{M}$ & 72 & SCC & L. $B^{8} B^{9} B^{10}$ & Cis & nodular & $5 \times 8$ & COPD & $8 \mathrm{M}$ & $\begin{array}{l}\text { dead by } \\
\text { another carcinoma }\end{array}$ \\
\hline 6 & M & 61 & $\mathrm{SCC}$ & L. $\mathrm{B}^{1+2} \mathrm{~B}^{3}$ & Cis & $\begin{array}{l}\text { surface- } \\
\text { invasion }\end{array}$ & $6 \times 8$ & COPD & $120 \mathrm{M}$ & alive \\
\hline \multirow[t]{2}{*}{7} & M & 68 & $\mathrm{SCC}$ & 1)R. $\mathrm{B}^{1} \mathrm{~B}^{2}$ & Cis & $\begin{array}{l}\text { surface- } \\
\text { invasion }\end{array}$ & $6 \times 9$ & COPD & $75 \mathrm{M}$ & alive \\
\hline & & & & 2)L.B. ${ }^{4} B^{5}$ & Cis & $\begin{array}{l}\text { surface- } \\
\text { invasion }\end{array}$ & $5 \times 7$ & & & \\
\hline 8 & M & 76 & SCC & R. $\mathrm{B}^{1} \mathrm{~B}^{2}$ & Cis & $\begin{array}{l}\text { surface- } \\
\text { invasion }\end{array}$ & $4 \times 8$ & COPD & $11 \mathrm{M}$ & alive \\
\hline
\end{tabular}

SCC : squamous cell carcinoma, Cis : carcinoma in situ.

かけて，8例のROLCに対してPDTを施行し， その適応, 照射範囲, 治療効果判定, 追加治療 の必要性などについて検討した。

\section{研究対象および方法}

1982年から1993年にかけて当科に入院した気 管支原発の中枢型早期肺癌患者 8 例10病巣を対 象とした (Table 1). 性別は全例男性で, 年齢は 61歳から76歳(中間値71歳)であった。組織型は 全例が扁平上皮癌で, TNM分類ではTisN0M0 は 6 例 8 病巣 (多発癌 2 例), T1N0M0は 2 例 2 病巣であった。発生部位は区域気管支までが 7 例で 9 病巣, 覀区域気管支が 1 例 1 病巣であっ た. 病型は表層浸潤型が最も多く5例 6 病巣, 結 節隆起型が 2 例 3 病巣, ポリープ型は 1 例 1 病 巣であった。腫瘍径の判定は気管支鏡所見によ $\eta$, 正常気管支径を基準として測定し, 長軸方向 の進展の可能性をも考慮し最大径をもって径と した ${ }^{4)}$.この基準による腫瘍径は, 10mm未満であ ったのが 6 例 7 病巣, $10 \mathrm{~mm}$ 以上と判定された のは 2 例 3 病巣であった. PDTが選択された理 由は,いずれも合併症 (肺気腫 6 例, 塵肺 2 例)に 起因する低肺機能 $(\mathrm{VC} \leqq 1000 \mathrm{ml})$ によっていた。 PDTの方法は, Photofrin I 2.5から5.0 $\mathrm{mg} / \mathrm{kg}$ (平均 $3.04 \mathrm{mg} / \mathrm{kg}$ ), またはPhotofrin II を $2.0 \mathrm{mg} / \mathrm{kg}$ 静注し，その 48 時間後に総量 $180 \mathrm{~J}$ の Argon-dye LaserもしくはExcimer-dye Laserを病巣部およびその周囲約 $5 \mathrm{~mm}$ 範囲 に15分から20分かけて照射した(Fig. 1)。レー ザ一照射後は，急性炎症やphotodynamic reactionによって生ずる壊死性分泌物による閉塞性 肺炎を予防するために，1週間は気管支鏡によ り毎日除痰した。また，Photofrinによる日光過 敏性皮膚炎を防止するために 3 週間は遮光を施 した. 治療効果の判定は, PDT施行 2 週後の気 管支鏡検查による病巣部の腫瘍縮小または消失 の所見と, 生検組織診の結果に加えて, PDT施 行後 2 週後と 4 週後の喀痰細胞診の結果により 総合的に行った．治療効果の判定基準は，喀痰 細胞診にはPapanicolaou分類を, 生検組織診に は大星・下里分類 ${ }^{5}$ を用いた。喀痰細胞診はclass I 〜 III a complete response $(\mathrm{CR})$, IIIb V を partial response $(\mathrm{PR})$ とした。生検組織診は non-viableな癌細胞の有無を $\mathrm{CR}$ とRの判定基 準として I 〜 IIbはPR，III〜IVはCRとした. 効 果判定後は 3 力月に 1 度の喀痰細胞診もしくは 気管支鏡による生検組織診による経過観察を行 った。 
Fig. 1. Method of photodynamic therapy.

Photofrin I $2.5 \sim 5.0 \mathrm{mg} / \mathrm{kg}$ i.v.

or

Photofrin II $2.0 \mathrm{mg} / \mathrm{kg}$ i.v.

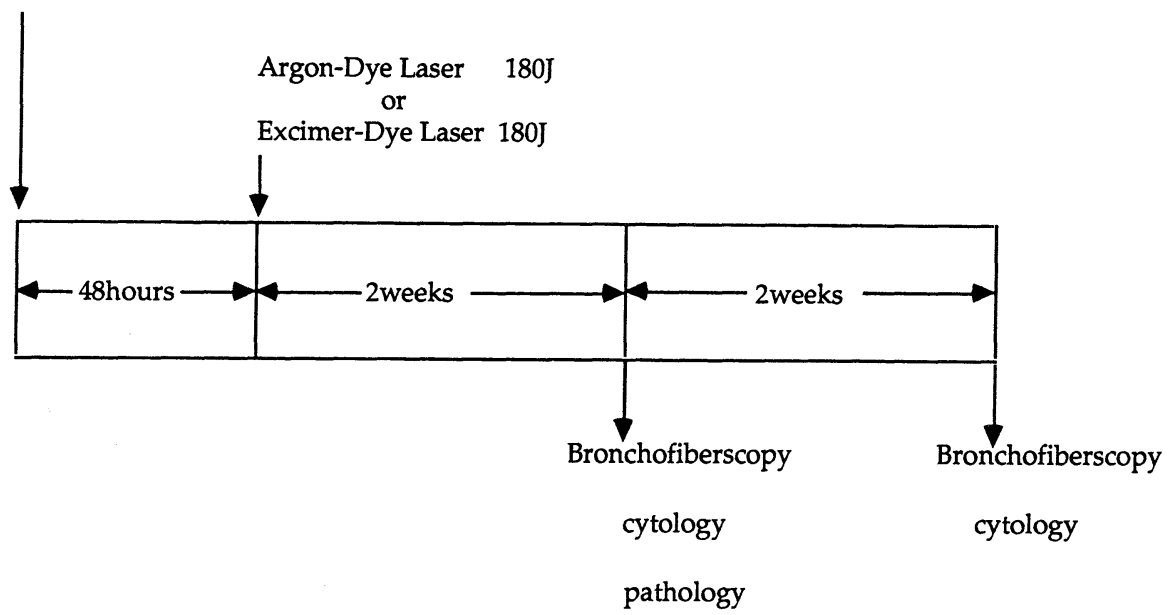

\section{結 果}

1. 治療効果判定と結果 (Table 2)

気管支鏡所見では全例に著明な腫 瘍の縮小，もしくは消失が認められ た. 2 週後及び 4 週後の組織診・細 胞診ともCRを示LCRと判定された のは症例 $1,2,6,7$ の 4 例であっ た. 残りの 4 例中 1 例は, 2 週後は $\mathrm{PR}$ であったが 4 週後にCRとなり， その後もCRを持続 (症例 3 ) した。他 の 3 例 (症例 $4,5,8$ ) は 2 週後, 4 週後ともPRであったためPRと判定 された.したがって最終的にCRを 5 例, PRを 3 例得た.

\section{CR症例の検討}

CRの 5 例において以下の点について検討し た. 腫瘍の部位は区域気管支が 4 例 6 病巣, 亜 区域支が 1 例 1 病巣であった。単発腫瘲が 3 例, 多発腫瘍は 2 例に認められた。気管支鏡による 組織生検標本から判定した浸潤度は, Cisが 4 例 6 病巣で, T1が 1 例 1 病巣であった。腫瘍径 は, $10 \mathrm{~mm}$ 未満のものが 4 例 5 病巣, $10 \mathrm{~mm}$ 以上 を示したのは 1 例 2 病巣であった.PDT後の経 過観察中に局所再発を 2 例 (症例 1,7 ) に認め た. 症例 1 は早期肺癌の治療前にすでに他の部
Table 2. Therapeutic effect by PDT and additional therapy.

\begin{tabular}{|c|c|c|c|c|c|}
\hline case & \multicolumn{2}{|c|}{ 2week } & 4week & local & additional \\
\hline & cytology & pathology & cytology & & \\
\hline 1 & $\mathrm{CR}$ & $\mathrm{CR}$ & $\mathrm{CR}$ & $(+)$ & \\
\hline 2 & $\mathrm{CR}$ & $\mathrm{CR}$ & $\mathrm{CR}$ & $(-)$ & \\
\hline 3 & PR & PR & $\mathrm{CR}$ & $(-)$ & \\
\hline 4 & PR & PR & PR & & Radiation \\
\hline 5 & PR & PR & PR & & \\
\hline 6 & CR & CR & $\mathrm{CR}$ & $(-)$ & \\
\hline 7 & CR & $\mathrm{CR}$ & CR & $(+)$ & Radiation \\
\hline 8 & PR & PR & PR & & Radiation \\
\hline
\end{tabular}

位に癌があり, 肺癌は多発で腫瘍径は $15 \times 15$ $\mathrm{mm}, 11 \times 12 \mathrm{~mm}$ であった. PDTの 6 カ月後に局 所再発し，局所再発に加之他の癌からと思われ る骨転移を認めたため放射線治療せずに 48 力月 後に死亡した。症例 7 は 2 病巣ともに 14 月後 に局所再発を認め，いずれにも放射線治療を追 加し，その後再発を認めていない。局所再発を 認めなかった 3 例中, 症例 2 はPDTの 40 カ月後 に原発巣不明の未分化癌が発症し, 再発時すで に対側リンパ節に転移を認めたため追加治療せ ずに62カ月後に死亡した。剖検時の所見では， 未分化癌の全身性の転移がみられたが，気管支 には扁平上皮癌は認めなかった。症例 3 は39カ 
月後に脳出血の合併により死亡した。症例 6 は 120力月後も健在である. 5 例全体の生存期間は $39 \sim 120$ 力月 (中間值50力月) で, うち 2 例は現在 も生存中である。

\section{PR症例の検討}

PRであった 3 例の発生部位は全例区域気管 支で, 浸潤度はCis 2 例, T 1 が 1 例であった。腫 瘍径は $10 \mathrm{~mm}$ 未満のものが 2 例, $10 \mathrm{~mm}$ 以上だ ったのは 1 例であった. 3 例中 2 例 (症例 4,8 ) に, PDT後放射線治療を追加しいずれもCRを 得た。症例 4 は肺炎により42力月後に死亡した。 局所再発は認められなかった。症例 5 は重複し た肺腺癌が進行したため, 放射線治療を追加せ ず 8 カ月後に死亡した。症例 8 は現在も生存中 で，再発は認められていない。

\section{CR症例とPR症例の比較 (Table 3)}

$\mathrm{CR}$ 症例と $\mathrm{PR}$ 症例の背景因子を以下に対比し た. 発生部位では, 亜区域支発生をCRの 1 例に 認めたのみで他はすべて区域気管支であり，

$\mathrm{CR}, \mathrm{PR}$ 群間の発生部位には差は見られなかっ た. 深達度と腫瘍径について, 多発例の 2 病巣 を含めた 10 病巣で比較すると, 深達度ではCisの 6 例中 4 例, 8 病巣中 6 病巣にCRを得た. Cisの 2 例， 2 病巣ではPRであった。腫瘍径では 10 $\mathrm{mm}$ 未満の 6 例中 4 例, 7 病巣中 5 病巣にCRを 得た.他の 2 例, 2 病巣ではPRであった. $10 \mathrm{~mm}$ 以上では 2 例, 3 病巣中 1 例, 2 病巣がCRだっ たが，その症例は 6 力月後に再発した。 今回の 検討では, 症例数が少なく CR例と PR例の間に は明らかな差異は認められなかった。

\section{考 案}

PDTは，高齢者や肺気腫等による低肺機能に より手術適応外とされた中枢型早期肺癌患者に 対する治療法として，1980年代前半より ${ }^{6)}$ 臨床 に導入された。現在では限られた施設ではある が，有効性や長期生存例の報告7もみられるよ うになってきた.PDTのCR率からみたPDTの 適応について, Furuseら ${ }^{8)}$ は, stage分類, 腫瘍 径, 腫瘍発生部位，気管支鏡所見 (表層浸潤型, ポリープ型, 結節隆起型)の面から検討し, 以下 の結果を報告している。すなわち, 中枢型早期
Table 3. Comparison between $\mathrm{CR}$ case and $\mathrm{PR}$ case.

\begin{tabular}{|c|c|c|c|}
\hline & & $\mathrm{CR}$ case & PR case \\
\hline \multirow{2}{*}{ location } & $\begin{array}{l}\text { segmental } \\
\text { bronchus }\end{array}$ & 6 & 3 \\
\hline & $\begin{array}{l}\text { subsegmental } \\
\text { bronchus }\end{array}$ & 1 & 0 \\
\hline \multirow{2}{*}{$\mathrm{T}$ factor } & CIS & 6 & 2 \\
\hline & $\{\mathrm{T} 1$ & 1 & 1 \\
\hline \multirow{2}{*}{ size (mm) } & $\{<10 \mathrm{~mm}$ & 5 & 2 \\
\hline & $\{10 \mathrm{~mm} \leqq$ & 2 & 1 \\
\hline
\end{tabular}

肺癌に対するPDTのCR率は全体で $84.8 \%$ であ り, 浸潤度がCisおよび腫瘍径は気管支鏡可視範 囲上 $10 \mathrm{~mm}$ 未満をPDTの適応と限るとCR率は Cisでは $100 \%$, 腫瘍径 $10 \mathrm{~mm}$ 未満では $97.8 \%$ と 報告している，本検討におけるCR率は全体で $62.5 \%$ ( 8 例中 5 例, 10 病巣中 7 病巣), 浸潤度 ではCis で $66.7 \%$ ( 6 例中 4 例, 8 病巣中 6 病 巣), 腫瘍径では $10 \mathrm{~mm}$ 未満で $66.7 \%$ ( 6 例中 4 例, 7 病巣中 5 病巣)であり, 適応を限定したの

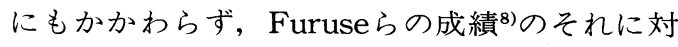
し低率であった。

PDTによるCR率には照射レーザーの組織到 達度と照射範囲が影響すると考えられる。レー ザー光の到達度については, Argon-dye Laser では表層より $5 \mathrm{~mm}$ か $10 \mathrm{~mm}$, Excimer-dye Laserは $15 \mathrm{~mm}$ から $20 \mathrm{~mm}$ までの組織到達度が 期待できるとされており ${ }^{9)}$, Cisまたは T1症例で はレーザー光の到達については問題はないと思 われる、レーザ一光の照射範囲については明確 な基準は示されていないが，我々は気管支鏡上 の腫瘍と思われる部とその周囲約 $5 \mathrm{~mm}$ の範囲 にレーザー光を照射した. しかし，気管支鏡に よる腫瘍範囲の決定は術者の観察によるため, 表層は正常粘膜でもその下に癌組織が存在して いたり，軟骨・平滑筋層下に癌組織が存在して いた場合，これを気管支鏡により診断すること は難しい，また，気管支の長軸方向に癌が進展 している時は，気管支鏡上腫瘍範囲を過少評価 する可能性がある. 今回の検討において, CR後 に局所再発した症例は 2 例とも 2 病巣の症例で, 腫瘍範囲を過少評価した可能性は否定できない。 
従ってPDTの治療成績を高めるためには, 術前 に腫瘍と思われる部位のさらに周囲をも含めて 生検の上, 腫瘍範囲を厳密に判定し, かつレー ザ一照射範囲を設定する必要があると考える。 また生検標本上の粘膜上皮，気管軟骨，平滑筋 の存在を充分に評価する必要があると思われ $3^{10)}$.

PDTによる効果がPRにとどまるか，PDT後 局所再発した症例への追加治療については, 放 射線療法, 化学療法, 縮小手術等が考えられる. 癌の局在があきらかで, PDTによる腫瘍縮小効 果の充分な時期での放射線治療では, 最小限の 照射野と線量による治療が可能で, 合併症の頻 度の低減と良好な治療効果が期待できる。 今回 の検討では，PDTでPRにとどまった 3 例のう ち 2 例とCR後再発した多発癌の 1 例の計 3 例 に放射線治療を施行し，いずれもCRを得ること ができた．今回の少数例の成績からは結論的な ことは言い得ないが, PDTの効果がPRもしく は再発を見た例に対する放射線治療の追加が有 効である可能性が考えられる ${ }^{11), 12)}$.

治療効果の判定とその時期については, 現在 までのところ確立した見解は得られていない。 本検討では, Furuseらの方法 ${ }^{8}$ に準じて, PDT 2 週後の気管支鏡所見および生検組織診と, PDT後連日施行した喀痰細胞診のうち 2 週後
と 4 週後の結果を総合して効果を判定した. PDT後の組織学的検討によると, 腫瘍は約 2 週 までに崩壊し，その後粘膜組織が正常に復する まで約 4 週を要するとされている10),12). 今回の 検討では 2 週後はPRであったが 4 週後にCR なった症例が 1 例あり, 効果判定時期は 4 週後 が良いと思われる。

PDTが臨床に導入されてまだ日が浅く，それ による 5 年生存率を検討した報告は少ない。 Furuse ${ }^{8) や O n o ~}{ }^{11)}$ の報告によると， 5 年生 存率は $40 \sim 60 \%$ と手術に比べ決して高いとはい えない. 今回の検討では早期死亡の 1 例と, 経 過観察中の 1 例を除き全例 3 年以上生存し，ま た 5 年以上の生存は 3 例で 5 年生存率は $42.8 \%$ ( 7 例中 3 例)であった。 5 例の死亡例のうち 5 例ともPDTの対象になった肺癌以外の疾患に よって死亡した。とくに, 同時性あるいは異時 性重複癌が死亡例の 5 例中 3 例にみられた。

以上より, 手術適応でない中枢型早期肺癌に 対するPDTでは, Cisおよび腫瘍径が $10 \mathrm{~mm}$ 未満 を適応とし, 治療効果がPRだった症例には放射 線治療を追加することにより長期生存が期待で きると考えられる.PDTが患者の予後を改善す るかどうかについては, 比較試験による検討が 必要と思われる。

\section{文 献}

1) 加藤治文, 齋藤 宏, 小中千守, 他: 肺癌 (非小 細胞癌を中心に) 手術側より。癌の臨床 37 ： 1629-1634, 1991.

2) 古瀬清行, 久保田馨, 河原正明, 他：Roentgenographically occult lung cancerに対する photodynamic therapy (PDT)を中心とした非 観血的治療成績. 日本胸部臨床 $47: 373-378$, 1988.

3) Woolner LB, Fontana RS, Cortese DS : Roentgenographically occult lung cancer: pathologic findings and frequency of multicentricity during a 10-year period. Mayo Clin Poc 59 : 453-466, 1984.

4）小野良祐, 池田茂人, 成毛韶夫, 他: 気管支
アイバースコープによる気管支壁の癌浸潤範 囲決定に関す、研究. 肺癌 $16: 193-206,1976$.

5) Shimosato Y, Oboshi S, Baba K: Histological evaluation of effects of radiotherapy and chemotherapy for carcinoma. Jap J Clin Oncol $1:$ 19-35, 1971.

6) Hayata $\mathrm{Y}$, Kato H, Konaka C : Hematoporphyrin derivative and laser photoradiation in the treatment of lung cancer. Chest $81: 269$ $-277,1982$.

7) Kato H, Konaka C, Kawata N : Five-year disease-free survival of a lung cancer patient treated only by photodynamic therapy. Chest $90: 768-770,1986$. 
8) Furuse $K$, Fukuoka $M$, Kato $H$, et al: A prospective phase II study on photodynamic therapy with photofrin II for centrally located eary-stage lung cancer. J Clin Onco 11 : 1852-1857, 1993.

9）加藤治文, 鬼頭隆尚, 古瀬清行, 他： Photodynamic therapyの現状一特に早期癌に ついて. 癌と化学療法 17：1833-1838, 1990.

10）和田哲明：病理組織学的にみた肺癌に対する レーザー治療の効果. 肺癌 $26: 173-183,1986$.
11) Ono $R$, Ikeda $S$, Suemasu $K$ : Hematoporphyrin derivative photodynamic therapy in roentgenographically occult carcinoma of the tracheobronchial tree. Cancer $69: 1699$ $-1701,1992$.

12）中村 洋, 野村 敏, 三浦 剛, 他：Roentgenographically Occult Lung Cancer(ROLC)に対 するPhotodynamic therapy (PDT) と放射線療 法の併用例の検討.気管支学 $16: 33-39,1994$.

（原稿受付 1995 年 1 月 5 日／採択 1995年 2 月16日)

\title{
Effects of Photodynamic Therapy in Inoperable Early Stage Lung Cancer Patients
}

\author{
Naofumi Takehara, Yoshinobu Ohsaki, Satoru Fujiuchi, Shuji Yamaguchi, \\ Yuji Akiba, Hitoshi Nakano, Toshiaki Fujikane*, \\ Tetsuo Simizu*, Eiichi Sakai* and Kenjiro Kikuchi \\ First Department of Medicine, Asahikawa Medical College \\ *National Sanatorium Dohoku Hospital
}

Eight patients with early stage lung cancer underwent photodynamic therapy (PDT) using a flexible bronchofiberscope from 1982 to 1993 . All patients had one or two early epidermoid carcinomas in the central airway which were not detectable by chest radiography. Six patients, including two multiple primary cases had TisN0M0 lung cancers. Two patients had T1N0M0 lung cancers. Seven cancers in six patients were less than 10 $\mathrm{mm}$ in length, while three cancers in two patients were greater than $10 \mathrm{~mm}$ in length. Results of PDT were evaluated using biopsy specimens, sputum cytology and bronchofiberscopic observation at 2 and 4 weeks after the PDT. Five patients achieved complete response $(\mathrm{CR})$. Three patients achieved partial response (PR). In the 8 cancers in the 6 patients with carcinomas in situ, 6 cancers in the 4 patients achieved CR. In the 7 cancers in the 6 patients which were less than $10 \mathrm{~mm}$ in length, 5 cancers in 4 patients achieved $\mathrm{CR}$. One $\mathrm{CR}$ case that had local recurrence and $2 \mathrm{PR}$ patients received additional irradiation in the lung after the PDT and then achieved complete response. Median survival period was $50+$ months (range 39-120 months). Three patients survived more than five years. Three patients died from secondary cancer, another 2 patients died from diseases unrelated to the malignancy. No patient died from primary lung cancer. These results suggest that PDT is effective in the treatment of inoperable patients with early bronchial carcinoma. Careful evaluation of the disease, with extensive biopsy specimens and additional irradiation of $\mathrm{PR}$ patients or recurrent patients seem to contribute to control of the disease. 